\title{
Facile Synthesis of Lithium Sulfide Nanocrystals for Use in Advanced Rechargeable Batteries
}

\author{
Xuemin Li, ${ }^{\dagger}$ Colin A. Wolden, ${ }^{*}+$ Chunmei Ban, $^{\S}$ and Yongan Yang ${ }^{*} \dagger$ \\ ${ }^{\dagger}$ Department of Chemistry, Colorado School of Mines, 1012 14th Street, Golden, Colorado 80401, United States \\ ${ }^{\ddagger}$ Department of Chemical and Biological Engineering, Colorado School of Mines, 1613 Illinois Street, Golden, Colorado 80401, \\ United States \\ ${ }^{\S}$ National Renewable Energy Laboratory, 1617 Cole Boulevard, Golden, Colorado 80401, United States
}

\section{Supporting Information}

ABSTRACT: This work reports a new method of synthesizing anhydrous lithium sulfide $\left(\mathrm{Li}_{2} \mathrm{~S}\right)$ nanocrystals and demonstrates their potential as cathode materials for advanced rechargeable batteries. $\mathrm{Li}_{2} \mathrm{~S}$ is synthesized by reacting hydrogen sulfide $\left(\mathrm{H}_{2} \mathrm{~S}\right)$ with lithium naphthalenide (Li-NAP), a thermodynamically spontaneous reaction that proceeds to completion rapidly at ambient temperature and pressure. The

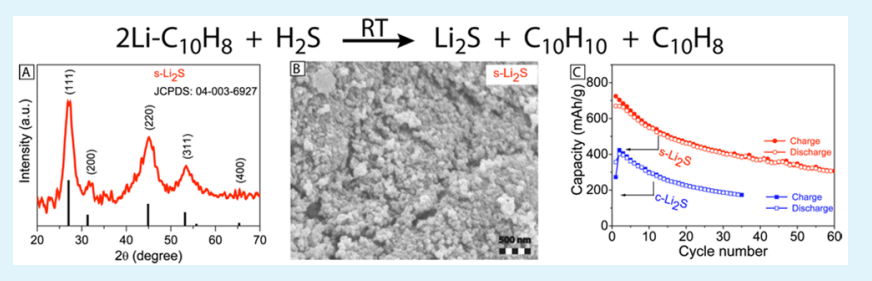
process completely removes $\mathrm{H}_{2} \mathrm{~S}$, a major industrial waste, while cogenerating 1,4-dihydronaphthalene, itself a value-added chemical that can be used as liquid fuel. The phase purity, morphology, and homogeneity of the resulting nanopowders were confirmed by X-ray diffraction and scanning electron microscopy. The synthesized $\mathrm{Li}_{2} \mathrm{~S}$ nanoparticles $(100 \mathrm{~nm})$ were assembled into cathodes, and their performance was compared to that of cathodes fabricated using commercial $\mathrm{Li}_{2} \mathrm{~S}$ micropowders $(1-5 \mu \mathrm{m})$. Electrochemical analyses demonstrated that the synthesized $\mathrm{Li}_{2} \mathrm{~S}$ were superior in terms of (dis)charge capacity, cycling stability, output voltage, and voltage efficiency.

KEYWORDS: lithium sulfide, lithium-sulfur batteries, synthesis, hydrogen sulfide, lithium naphthalenide

\section{INTRODUCTION}

Rechargeable batteries are ubiquitous power sources in our modern society. Their applications span from personal devices to national defense, from chemical sensors to human health, and from ground transportation to spacecrafts. ${ }^{1-3}$ Currently, the most advanced rechargeable batteries are lithium-ion batteries (LIBs, which typically employ graphite anodes and lithium-cobalt oxide cathodes). ${ }^{4}$ While they are superior to conventional counterparts (such as nickel-cadmium batteries), more advanced LIBs and beyond-lithium technologies with higher specific energy (energy per unit mass), higher energy density (energy per unit volume), lower cost, and safer chemistry/fabrication are imperative to meet the demand of sustainable development. ${ }^{4}$

Lithium-sulfur ( $\mathrm{Li}-\mathrm{S})$ batteries are widely considered the most promising power sources in the near future for developing more advanced portable devices, electric vehicles, and stationary energy-storage facilities. ${ }^{5}$ Compared with the currentgeneration LIBs, Li-S batteries hold two remarkable advantages: ${ }^{5,6}$ (1) presenting higher specific energy (2600 vs $580 \mathrm{Wh} / \mathrm{kg}$ ) and energy density (2200 vs $1800 \mathrm{Wh} / \mathrm{L}) ;(2)$ using earth-abundant and cost-effective materials in the cathode ( $\mathrm{S}$ vs $\mathrm{Co}$ ). However, the direct use of a lithium metal anode and a sulfur cathode ensues some challenges. ${ }^{7-9}$ First, cycling can lead to the formation of harmful dendrites on the lithium metal anode, which can grow and penetrate the separator, potentially causing short-circuit, thermal runaway, and even severe fire. ${ }^{8,10}$ Second, it is difficult to engineer the sulfur cathode to provide sufficient void space to accommodate the $80 \%$ volume expansion that accompanies lithiation, which often pulverizes the electrode and damages the electrical contact. ${ }^{8}$ An alternative approach that avoids these problems is to use lithium sulfide $\left(\mathrm{Li}_{2} \mathrm{~S}\right)$ as the cathode. ${ }^{11}$

While $\mathrm{Li}_{2} \mathrm{~S}$ and sulfur are both poor electronic and ionic conductors, which would typically preclude their use in electrochemical applications, $\mathrm{Li}_{2} \mathrm{~S}$ presents several advantages. ${ }^{11}$ First, the use of $\mathrm{Li}_{2} \mathrm{~S}$ avoids the problems associated with lithium metal anodes, and it can directly be paired with existing anode materials (graphite) as well as new lithium-free materials (such as silicon and tin) for assembling batteries. ${ }^{12}$ The practical specific energy of $\mathrm{Li}_{2} \mathrm{~S}-\mathrm{Si}(930 \mathrm{Wh} / \mathrm{kg}$ ) is close to that of a $\mathrm{Li}-\mathrm{S}$ battery $(1000 \mathrm{Wh} / \mathrm{kg}){ }^{9}$ Second, because of its much higher melting/boiling points, $\mathrm{Li}_{2} \mathrm{~S}$ permits a wider temperature window for electrode fabrication. ${ }^{4}$ Third, $\mathrm{Li}_{2} \mathrm{~S}$ is fully lithiated, not a requiring preset void space around $\mathrm{Li}_{2} \mathrm{~S}$ particles for accommodating the detrimental volume fluctuations that occur during the charge/discharge cycles. ${ }^{13,14}$ Fourth, although a dry room or glovebox is required for electrode fabrication, ${ }^{9} \mathrm{Li}_{2} \mathrm{~S}$ allows batteries to be assembled in the "discharged" state, a safer and more cost-effective process. ${ }^{8}$

Received: October 3, 2015

Accepted: December 3, 2015

Published: December 3, 2015 
Moreover, recently, scientists showed that the issues of poor electronic and ionic conductivity for $\mathrm{Li}_{2} \mathrm{~S}$ could be overcome by either applying a high activation potential or using nanoparticles. ${ }^{4,9,15}$ Therefore, $\mathrm{Li}_{2} \mathrm{~S}$ nanoparticles are highly desirable for developing $\mathrm{Li}-\mathrm{S}$ batteries; a large demand is expected in the near future.

However, commercially, $\mathrm{Li}_{2} \mathrm{~S}$ is only available as micropowders, reflecting high-temperature processes used for industrial synthesis. ${ }^{16,17}$ The primary techniques are ${ }^{16-19}$

$$
\begin{aligned}
& 2 \mathrm{Li}+\mathrm{S} \stackrel{T \geq 300^{\circ} \mathrm{C}}{\longrightarrow} \mathrm{Li}_{2} \mathrm{~S} \quad \Delta \mathrm{G}_{\mathrm{m}}{ }^{\circ}\left(\mathrm{Li}_{2} \mathrm{~S}\right) \approx-414 \mathrm{~kJ} / \mathrm{mol} \\
& \mathrm{Li}_{2} \mathrm{SO}_{4}+2 \mathrm{C} \stackrel{T=600-1000^{\circ} \mathrm{C}}{\longrightarrow} \mathrm{Li}_{2} \mathrm{~S}+2 \mathrm{CO}_{2} \\
& \Delta G_{\mathrm{m}}{ }^{\circ}\left(\mathrm{Li}_{2} \mathrm{~S}\right) \approx+119 \mathrm{~kJ} / \mathrm{mol} \\
& \mathrm{Li}_{2} \mathrm{CO}_{3}+\mathrm{H}_{2} \mathrm{~S} \stackrel{T=600-1000^{\circ} \mathrm{C}}{\longrightarrow} \mathrm{Li}_{2} \mathrm{~S}+\mathrm{H}_{2} \mathrm{O}+\mathrm{CO}_{2} \\
& \Delta G_{\mathrm{m}}{ }^{\circ}\left(\mathrm{Li}_{2} \mathrm{~S}\right) \approx+120 \mathrm{~kJ} / \mathrm{mol}
\end{aligned}
$$

Because lithium and sulfur both are very reactive at elevated temperatures, the operation of reaction (1) is challenging, although it is a thermodynamically favorable reaction. An alternative way of running reaction (1) is to dissolve lithium in liquid $\mathrm{NH}_{3}$ at $<-33{ }^{\circ} \mathrm{C}$, but this approach brings additional complications. Reactions (2) and (3) are endothermic carbothermal reduction processes that require high temperatures and produce greenhouse gas. In addition, product purification in these three methods is also expected to be complicated and costly because at least one reactant is in the same phase as $\mathrm{Li}_{2} \mathrm{~S}$.

Another drawback of current approaches is the size of the resulting powders $(1-10 \mu \mathrm{m})$. It is commonly reported in the battery literature that nanostructured materials are superior to their bulk counterparts. ${ }^{11}$ Large surface/volume ratios promote thorough lithiation/delithiation [high (dis)charge capacity], fast diffusion (high rate capability), and mechanical resilience (high cycling stability). ${ }^{11}$ Current approaches to convert $\mathrm{Li}_{2} \mathrm{~S}$ micropowders into nanocrystals include ball milling ${ }^{9,20-24}$ and recrystallization of dissolved $\mathrm{Li}_{2} \mathrm{~S}, 4,25-28$ but these approaches are both energy-intensive and time-consuming. A more elegant strategy would be the direct synthesis of $\mathrm{Li}_{2} \mathrm{~S}$ nanocrystals. One approach being pursued is chemical/electrochemical lithiation of sulfur nanoparticles, ${ }^{12,15,29-31}$ but this multistep process requires synthesis of well-dispersed sulfur nanoparticles. Recently, two research groups reported direct syntheses of $\mathrm{Li}_{2} \mathrm{~S}$ nanocrystals by reacting lithium sulfate with carbon precursors at high temperatures $\left(820-900{ }^{\circ} \mathrm{C}\right)$ for $>2 \mathrm{~h}^{32,33}$ Elam et al. synthesized amorphous $\mathrm{Li}_{2} \mathrm{~S}$ nanofilms using a vapor-phase atomic layer deposition via alternating exposure to lithium tert-butoxide and hydrogen sulfide. ${ }^{34}$ However, it seems challenging for these methods to produce $\mathrm{Li}_{2} \mathrm{~S}$ nanocrystals at large scale.

This work reports a scalable, high-throughput, room temperature approach to synthesizing $\mathrm{Li}_{2} \mathrm{~S}$ nanocrystals, by reacting hydrogen sulfide $\left(\mathrm{H}_{2} \mathrm{~S}\right)$ with lithium naphthalenide (Li-NAP), a thermodynamically spontaneous reaction that proceeds to completion rapidly at ambient pressure. The simple reaction directly generates $\mathrm{Li}_{2} \mathrm{~S}$ nanocrystals that precipitate out of solution, allowing easy recovery and purification. Because the value of $\mathrm{Li}_{2} \mathrm{~S}$ is many times higher than that of lithium, the cost of lithium seems less likely to be a limiting factor for industrial production. Furthermore, ancillary benefits of this reaction include the removal of $\mathrm{H}_{2} \mathrm{~S}$, a hazardous waste requiring abatement, and the production of 1,4-dihydronaphthalene, itself a value-added product with applications as an industrial solvent and a fuel additive. Electrochemical characterization of $\mathrm{Li}_{2} \mathrm{~S}$ nanocrystals synthesized in this work demonstrate its potential for use in $\mathrm{Li}-\mathrm{S}$ batteries and advanced LIBs, outperforming commercial $\mathrm{Li}_{2} \mathrm{~S}$ micropowders, in terms of (dis)charge capacity, cycling stability, output voltage, and voltage efficiency.

\section{EXPERIMENTAL SECTION}

2.1. Chemicals. Lithium ( $\mathrm{Li}$ ) grains (ACS reagent, stick dry), naphthalene (NAP, $\mathrm{C}_{10} \mathrm{H}_{8}, 99 \%$ ), anhydrous 1,2-dimethoxyethane (DME, $\mathrm{CH}_{3} \mathrm{OCH}_{2} \mathrm{CH}_{2} \mathrm{OCH}_{3}, 99.5 \%$ ), hexanes (ACS grade), lithium ribbon ( $99.9 \%$ trace metals basis, $0.38 \mathrm{~mm}$ ), bis(trifluoromethane)sulfonimide [LiTFSI, $\left(\mathrm{CF}_{3} \mathrm{SO}_{2}\right)_{2} \mathrm{NLi}, 99.95 \%$ ], and tetra(ethylene glycol) dimethyl ether [TEGDME, $\mathrm{CH}_{3} \mathrm{O}\left(\mathrm{CH}_{2} \mathrm{CH}_{2} \mathrm{O}\right)_{4} \mathrm{CH}_{3}, 99 \%$ ] were purchased from Sigma-Aldrich. Lithium sulfide $\left(\mathrm{Li}_{2} \mathrm{~S} ; 200\right.$ mesh, 99.9\% metal basis) was purchased from Alfa Aesar. Anhydrous benzene- $d_{6}\left(C_{6} D_{6}, D-99.5 \%\right)$ was purchased from Cambridge Isotope Lab. Acetylene black (AB; 35-45 nm), anhydrous $N$-methylpyrrolidone (NMP, $\mathrm{C}_{5} \mathrm{H}_{9} \mathrm{NO},>99.5 \%$ ), poly(vinylidene fluoride) [PVDF, $\left.-\left(\mathrm{C}_{2} \mathrm{H}_{2} \mathrm{~F}_{2}\right)_{n}-,>99.5 \%\right]$, and copper foil $(99.99 \%, 9 \mu \mathrm{m})$ were purchased from MTI Corp. AB and PVDF were dried in a vacuum oven at $60{ }^{\circ} \mathrm{C}$ for $24 \mathrm{~h}$ before use. All other chemicals were used as received.

2.2. Synthesis of $\mathrm{Li}_{2} \mathrm{~S}$. The first step is to make the $0.04 \mathrm{M}$ lithium naphthalenide (Li-NAP) solution in DME by adding Li grains and NAP powder at a molar ratio of Li:NAP $=1: 1.3$ into DME in an argon-protected glovebox. A total of $2 \mathrm{~h}$ of stirring produced a darkgreen solution. After that, a Parr reactor (model 4793) was charged with $50 \mathrm{~mL}$ of the Li-NAP solution and connected to the $\mathrm{H}_{2} \mathrm{~S}$ stream ( $10 \%$ in argon). Figure S1 illustrates the schematic diagram and photograph of the apparatus. Initially, the $\mathrm{H}_{2} \mathrm{~S} / \mathrm{Ar}$ mixture at a rate of $40 \mathrm{sccm}$ flowed through a bypass line at ambient temperature and pressure to create a baseline reading. Afterward, the $\mathrm{H}_{2} \mathrm{~S} / \mathrm{Ar}$ stream was switched to the Li-NAP solution. An online quadrupole mass spectrometer (QMS; Stanford Research Systems RGA300) was employed to analyze the effluent. The molar ratio between $\mathrm{Li}$-NAP and $\mathrm{H}_{2} \mathrm{~S}$ consumed was controlled by the $\mathrm{H}_{2} \mathrm{~S}$-flowing duration.

Subsequently, in the glovebox, centrifugation was employed to separate the solid product out of the reaction solution. The collected solid powder was washed with DME a few times before being dried for further analysis. The production yield of $\mathrm{Li}_{2} \mathrm{~S}$ on the basis of lithium was about $95.6 \%$, which was very satisfactory considering some loss of sample in the solution. The liquid phase was taken out of the glovebox and then concentrated via rotary evaporation to $1 / 5$ of the original volume. The collected solution was kept in the glovebox for further analysis.

2.3. Product Characterization. X-ray diffraction (XRD) patterns were collected on a Philips X'Pert X-ray diffractometer using $\mathrm{Cu} \mathrm{K} \alpha$ radiation $(\lambda=0.15405 \mathrm{~nm})$. The sample was prepared in a glovebox by pressing the solid product into a thin film on a glass substrate. To avoid harmful reactions due to unavoidable air exposure during measurements, the solid was immediately covered with a drop of dried mineral oil in the glovebox. The background contribution from mineral oil was subtracted and corrected. Scanning electron microscopy (SEM) images were taken on a field-emission scanning electron micrometer (JEOL JSM-7000F). The sample was prepared by immobilizing the obtained $\mathrm{Li}_{2} \mathrm{~S}$ powder on an aluminum stub using double-sided carbon tape. The accelerating voltage was $5 \mathrm{kV}$. Thermogravimetric analysis (TGA) was performed using a Q50 thermogravimetric analyzer (TA Instruments). The sample was prepared by pressing $\mathrm{Li}_{2} \mathrm{~S}$ powders into pellet inside an argon-filled glovebox. Before each run, the sample holder (an alumina pan) was cleaned by heating the furnace under air to $800{ }^{\circ} \mathrm{C}$ for $15 \mathrm{~min}$. To eliminate the influence of physisorbed gases during sample preparation, samples were also preheated at $50{ }^{\circ} \mathrm{C}$ for $30 \mathrm{~min}$ before collecting the valid TGA data. The nitrogen flow rate for the balance compartment and the argon flow rate for the sample compartment 

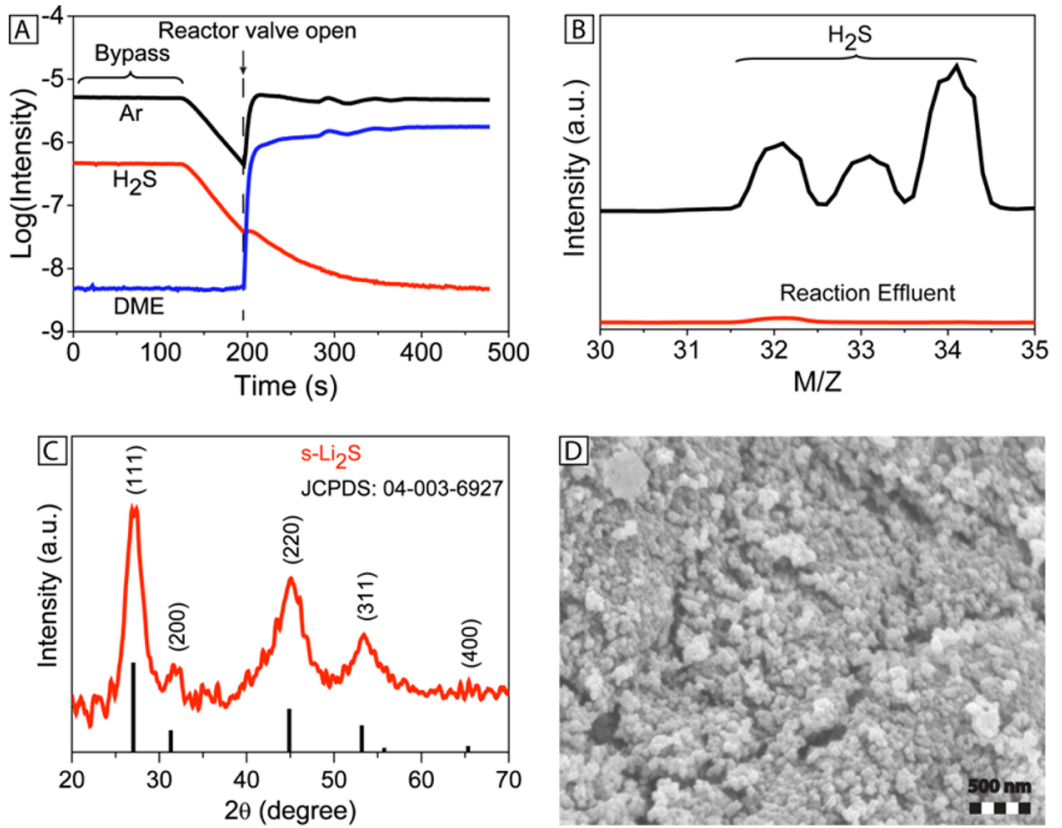

Figure 1. Characterization of the reaction for synthesizing $\mathrm{Li}_{2} \mathrm{~S}$ nanocrystals. (A) Time evolution of QMS to monitor the concentrations of key species in the gas phase: argon (black); $\mathrm{H}_{2} \mathrm{~S}$ (red); DME (blue). (B) MS spectra in the window of $m / z 30-35$ for the gaseous effluents through the bypass (black) and through the reactor (red). (C) XRD pattern of the obtained solid product (red) together with the stick pattern (black) of the $\mathrm{Li}_{2} \mathrm{~S}$ standard (JCPDS 04-003-6927). (D) SEM image of the obtained solid product.

were 40 and $60 \mathrm{~mL} / \mathrm{min}$, respectively. The temperature ramp rate was $2{ }^{\circ} \mathrm{C} / \mathrm{min}$.

The composition of the liquid supernatant produced by the reaction was analyzed by ${ }^{1} \mathrm{H}$ NMR (JEOL ECA-500) and gas chromatography-mass spectrometry (GC-MS). For NMR, $0.3 \mathrm{~mL}$ of the sample solution was dissolved in $0.2 \mathrm{~mL}$ of benzene- $d_{6}$ and loaded in a quartz sample tube. GC-MS analysis was conducted on a Varian CP3800 gas chromatograph coupled to a Varian 1200 L quadrupole mass spectrometer, for which the solid phase in the separation column is $5 \%$ diphenylpolysiloxane and 5\% dimethylpolysiloxane. The precondition of the column was accomplished by injecting pure solvent DME at 320 ${ }^{\circ} \mathrm{C}$. After that, the sample analysis was performed by injecting $1 \mu \mathrm{L}$ of the sample solution with the column temperature at $250{ }^{\circ} \mathrm{C}$. In both cases, the flow rates of the carrier gas of helium were $1.3 \mathrm{~mL} / \mathrm{min}$.

2.4. Electrode Fabrication and Electrochemical Analyses. Swagelok cell electrodes were fabricated to assess the electrochemical properties of the synthesized $\mathrm{Li}_{2} \mathrm{~S}$. Electrode fabrication began by first drying the as-synthesized $\mathrm{Li}_{2} \mathrm{~S}$ powder under argon in a tube furnace at $250{ }^{\circ} \mathrm{C}$ for $20 \mathrm{~h}$ to completely remove DME and NAP used in the synthesis. After that, the dried $\mathrm{Li}_{2} \mathrm{~S}$ (40 wt \%), $\mathrm{AB}$ (45 wt \%), and PVDF binder ( $15 \mathrm{wt} \%)$ were blended manually in a mortar. The resultant mixture was dispersed in a small amount of NMP and stirred overnight. Next, the obtained slurry was bladed onto a carbon paper (AvCarbP50) collector and dried at $110{ }^{\circ} \mathrm{C}$ for $6 \mathrm{~h}$. Then, the electrodes were cut into small disks of $10 \mathrm{~mm}$ diameter using a compact precision disk cutter (MTI Corp., MSK-T-07). The mass loading of $\mathrm{Li}_{2} \mathrm{~S}$ was around $1.0 \mathrm{mg} / \mathrm{cm}^{2}$. For benchmarking purposes, identical procedures were used to fabricate electrodes employing commercial $\mathrm{Li}_{2} \mathrm{~S}$ micropowders. Last, the half-cell batteries were assembled by using a lithium ribbon as the anode, a polypropylene membrane (Celgard 2500) as the separator, and 1.0 M LiTFSI in TEGDME as the electrolyte. Cyclic voltammograms (CVs) were collected on a potentiostat (Princeton Applied Research, Versastat 4). The cycling stability was assessed via the galvanostatic technique at 0.1 $\mathrm{C}(1 \mathrm{C}=1166 \mathrm{~mA} / \mathrm{g})$ by using an eight-channel battery analyzer (MTI Corp., BST8-MA). The specific capacity was calculated according to the mass of $\mathrm{Li}_{2} \mathrm{~S}$.

\section{RESULTS AND DISCUSSION}

3.1. Demonstration of the Synthetic Method. On the basis of our previous work of abating $\mathrm{H}_{2} \mathrm{~S}$ with sodium naphthalenide (Na-NAP), ${ }^{35}$ the $\mathrm{Li}_{2} \mathrm{~S}$ synthesis reaction is expected to be eq 4 and will be verified step by step.

$$
2 \mathrm{LiC}_{10} \mathrm{H}_{8}+\mathrm{H}_{2} \mathrm{~S} \rightarrow \mathrm{Li}_{2} \mathrm{~S}+\mathrm{C}_{10} \mathrm{H}_{10}+\mathrm{C}_{10} \mathrm{H}_{8}
$$

Figure 1A plots the time evolution of the signal intensities from the carrier gas argon (black), the solvent DME (blue), and the reactant $\mathrm{H}_{2} \mathrm{~S}$ (red) recorded by the online QMS, for a typical reaction using the stoichiometric molar ratio of $\mathrm{Li}$ $\mathrm{NAP}: \mathrm{H}_{2} \mathrm{~S}=2: 1$. Initially, the $\mathrm{H}_{2} \mathrm{~S} / \mathrm{Ar}$ mixture flowed through a bypass line to establish a baseline reading. When the bypass was closed at $t=127 \mathrm{~s}$, both argon and $\mathrm{H}_{2} \mathrm{~S}$ fall exponentially with a time constant characteristic of the gas dynamics of the sampling apparatus. At $t=195 \mathrm{~s}$, the inlet and outlet valves of the reactor were opened simultaneously, and the argon signal immediately returns to its original value, accompanied by a step change in the signals associated with the volatile DME solvent. In stark contrast, the $\mathrm{H}_{2} \mathrm{~S}$ signal continues to exponentially decay, eventually dropping below the instrument's detection limit. This indicates that the $\mathrm{H}_{2} \mathrm{~S}$ supplied has been consumed at least 99.9\%. The mass spectrum recorded from the effluent (Figure $1 B$, red) shows no signals of $\mathrm{H}_{2} \mathrm{~S}$ across the mass/charge $(\mathrm{m} / \mathrm{z})$ range of 32-34, while that recorded from the bypass mode (Figure 1B, black) shows the expected signals of $\mathrm{H}_{2} \mathrm{~S}$ evidently. Thus, the consumption of $\mathrm{H}_{2} \mathrm{~S}$ through its reaction with LiNAP is demonstrated to be spontaneous, complete, and nearly instantaneous, as previously observed for the Na-NAP system. ${ }^{35}$

As shown in Figure 1C (red), the XRD pattern of the obtained solid product is well consistent with that of the $\mathrm{Li}_{2} \mathrm{~S}$ standard (black), indicating the successful generation of anhydrous, phase-pure, crystalline $\mathrm{Li}_{2} \mathrm{~S}$. According to the Scherrer equation, which correlates crystalline domains with the peak width, $\mathrm{Li}_{2} \mathrm{~S}$ crystals are $\sim 5 \mathrm{~nm}$ in diameter. ${ }^{36}$ The 

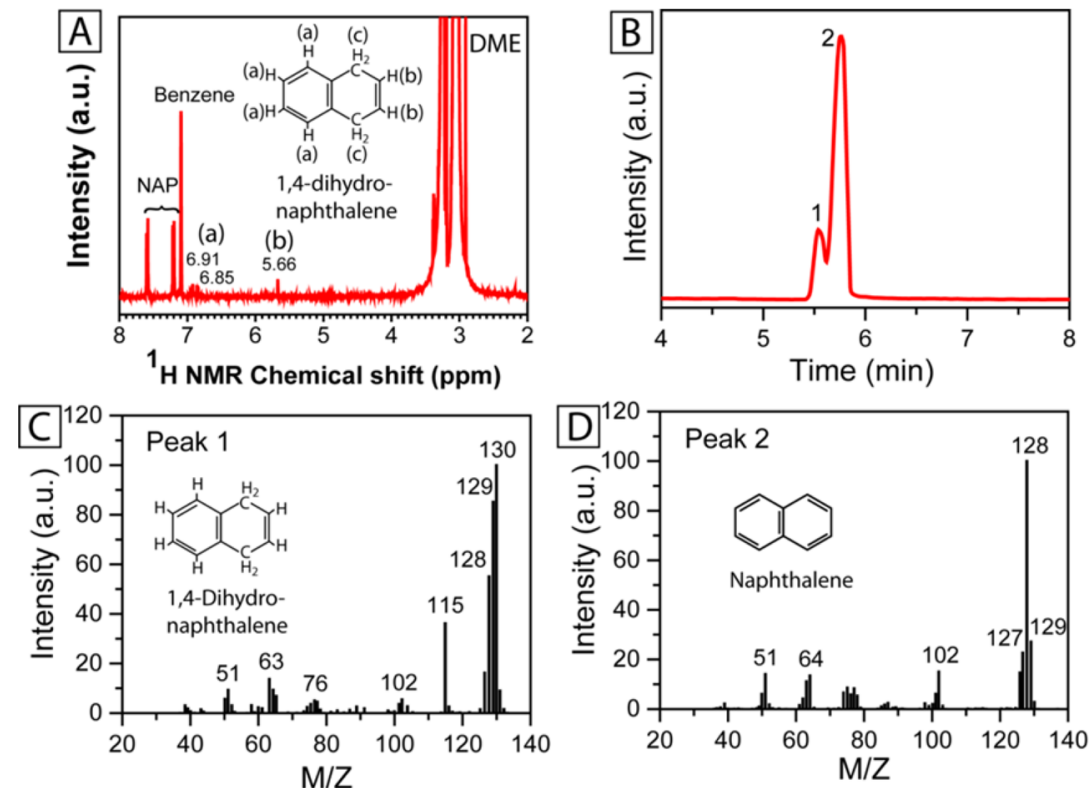

Figure 2. Characterization of the liquid phase collected from the synthetic reaction: (A) ${ }^{1} \mathrm{H}$ NMR spectrum; (B) gas chromatogram; (C) MS spectrum of peak 1 in part B; (D) MS spectrum of peak 2 in part B.
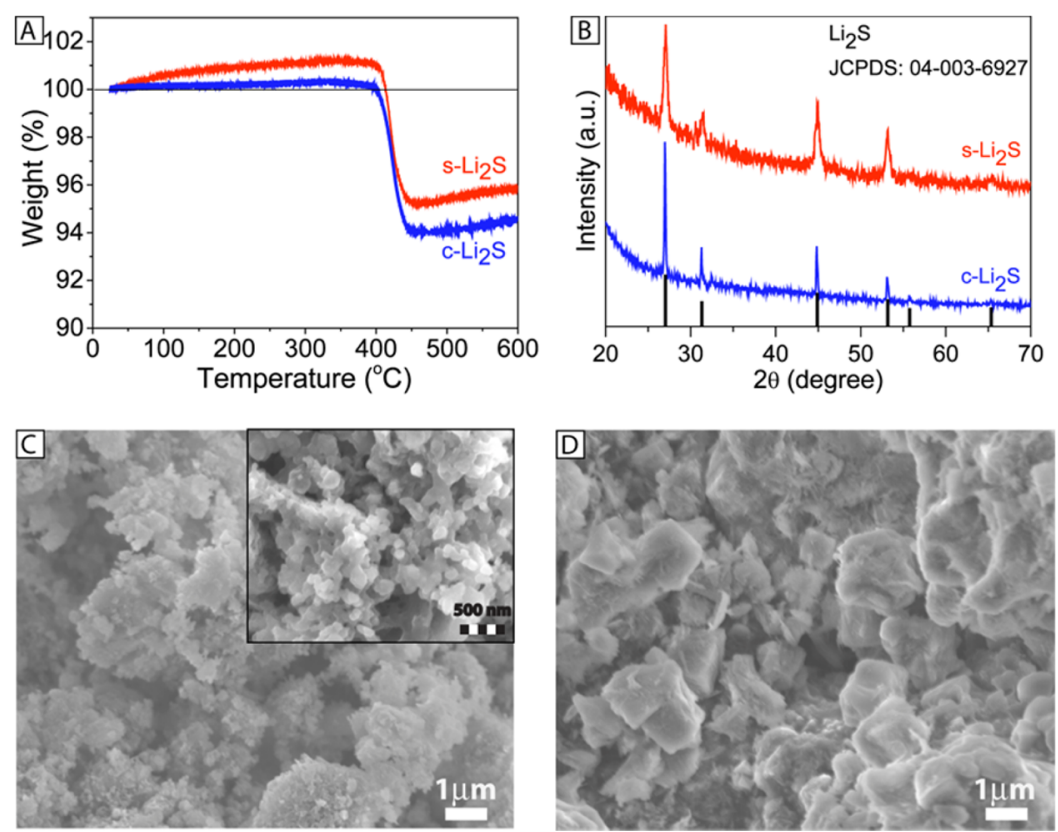

Figure 3. Characterization of $\mathrm{s}-\mathrm{Li}_{2} \mathrm{~S}$ (red) after being dried at $250^{\circ} \mathrm{C}$ for $20 \mathrm{~h}$ prior to electrochemical analyses, with c- $\mathrm{Li}_{2} \mathrm{~S}$ (blue) as a reference: $(\mathrm{A})$ TGA plots; (B) XRD patterns; (C) SEM image of s- $\mathrm{Li}_{2} \mathrm{~S}$; (D) SEM image of c- $\mathrm{Li}_{2} \mathrm{~S}$.

SEM image (Figure 1D) shows that $\mathrm{Li}_{2} \mathrm{~S}$ nanocrystals aggregate as secondary particles of $\sim 100 \mathrm{~nm}$.

The ${ }^{1} \mathrm{H}$ NMR spectrum of the liquid phase, obtained by using benzene- $d_{6}$ as the solvent, is shown in Figure 2A. Besides the expected benzene, DME, and NAP, ${ }^{37}$ three peaks at $6.91-$ $5.66 \mathrm{ppm}$ are assigned to the hydrogen atoms at positions a and $\mathrm{b}$ of 1,4-dihydronaphthalene. ${ }^{38}$ The signal of the hydrogen atoms at position $\mathrm{c}$ is expected to show up at 3.3-2.9 ppm but is masked by the intense signal of DME. The chromatogram recorded by $\mathrm{GC}-\mathrm{MS}$ (Figure $2 \mathrm{~B}$ ) shows two peaks. The corresponding MS spectra can be indexed to 1,4-dihydronaphthalene and NAP, respectively. ${ }^{39,40}$ Thus, the characterization results shown in Figures 1 and 2 prove that the $\mathrm{Li}_{2} \mathrm{~S}$ synthesis follows eq 4 , as previously observed for the Na-NAP system. ${ }^{35}$
Note that this synthetic method enables facile operation/ separation because the reactants and products exist in different phases.

Then, we tested the effect of the molar ratio of $\mathrm{Li}-\mathrm{NAP} / \mathrm{H}_{2} \mathrm{~S}$ on the $\mathrm{Li}_{2} \mathrm{~S}$ synthesis (Figure $\mathrm{S} 2$ ). At the ratios of $3: 1$ and 1.5:1, the solid products were also phase pure anhydrous $\mathrm{Li}_{2} \mathrm{~S}$ nanocrystals with comparable sizes and shapes as in the case of the stoichiometric $2: 1$. Differently, in the case of $1: 1$, which was expected to produce LiHS, no solid product was observed in the reaction system. After evaporation of the solvent, only a gellike substance was obtained, showing no sign of crystals. ${ }^{1} \mathrm{H}$ NMR did not produce any meaningful signals that could be assigned to known compounds. We believe that this is because LiHS fully dissolves in DME and exists in some unknown 

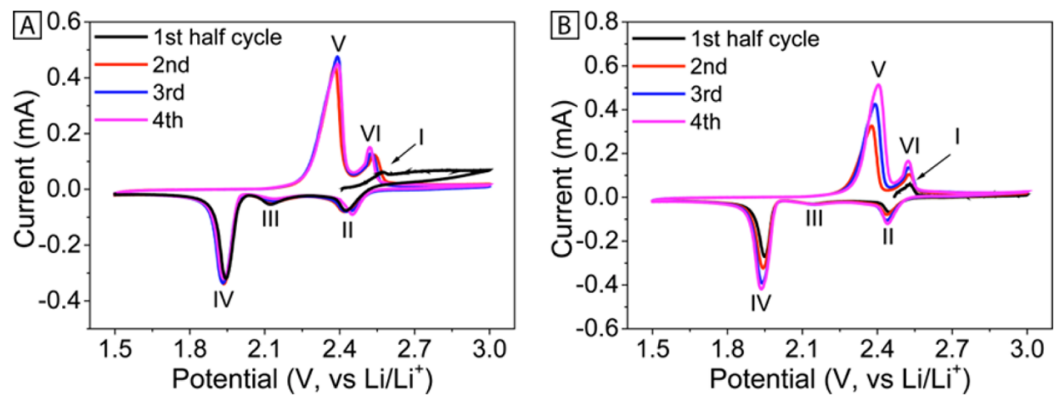

Figure 4. Typical CVs in the first four cycles of $s-\mathrm{Li}_{2} \mathrm{~S}(\mathrm{~A})$ and $\mathrm{c}-\mathrm{Li}_{2} \mathrm{~S}(\mathrm{~B})$, where the scan rate is $0.1 \mathrm{mV} / \mathrm{s}$.

complex form. For example, it is known that LiHS cannot precipitate out of ethanol but forms a LiHS/ethanol complex. ${ }^{41}$ The comparison with our previous work indicates that LiHS has higher solubility/complexity in DME than NaHS. ${ }^{35}$ These results demonstrate the robustness of this synthetic method to produce phase-pure $\mathrm{Li}_{2} \mathrm{~S}$ nanocrystals, and for practical operation, the use of a stoichiometric mixture is ideal to fully consume $\mathrm{H}_{2} \mathrm{~S}$ while maximizing the conversion of lithium to $\mathrm{Li}_{2} \mathrm{~S}$.

3.2. Structural and Electrochemical Analyses. The synthesized $\mathrm{Li}_{2} \mathrm{~S}$ nanocrystals (denoted as $\mathrm{s}-\mathrm{Li}_{2} \mathrm{~S}$ ) were further characterized after drying to remove residual organics. The TGA plots in Figure 3A show that $s-\mathrm{Li}_{2} \mathrm{~S}$ (red) has a purity comparable to that of the commercial $\mathrm{Li}_{2} \mathrm{~S}$ micropowders (denoted as $\mathrm{c}-\mathrm{Li}_{2} \mathrm{~S}$, blue), as indicated by their nearly identical weight-loss profiles, of which the overall difference is only $1 \%$. We speculate that the abrupt weight loss at about $400{ }^{\circ} \mathrm{C}$ is likely to result from the decomposition of some unknown impurities because the melting point of pure $\mathrm{Li}_{2} \mathrm{~S}$ is above 900 ${ }^{\circ} \mathrm{C} .{ }^{19}$ Possible culprits include lithium hydroxide $(\mathrm{LiOH})$, hydrogen sulfide $\left(\mathrm{H}_{2} \mathrm{~S}\right)$, and lithium carbonate $\left(\mathrm{Li}_{2} \mathrm{CO}_{3}\right){ }^{16,42}$ which could be formed via the reaction between trace amounts of $\mathrm{H}_{2} \mathrm{O}$ and $\mathrm{CO}_{2}$ with $\mathrm{Li}_{2} \mathrm{~S}$ during sample storage and handling in the glovebox and environment. ${ }^{43}$ The slight weight increase before $400{ }^{\circ} \mathrm{C}$ may be ascribed to the reaction of $\mathrm{Li}_{2} \mathrm{~S}$ with trace amounts of $\mathrm{H}_{2} \mathrm{O}, \mathrm{O}_{2}$, and/or $\mathrm{CO}_{2}$ in the carrier gas, which results in a greater reaction in the case of $\mathrm{s}-\mathrm{Li}_{2} \mathrm{~S}$ due to its larger surface/volume ratio than $\mathrm{c}-\mathrm{Li}_{2} \mathrm{~S}$. XRD patterns in Figure $3 \mathrm{~B}$ indicate a slight growth of the crystalline sizes for $\mathrm{s}-\mathrm{Li}_{2} \mathrm{~S}$ from the original $5 \mathrm{~nm}$ to the present $20 \mathrm{~nm}$ after heat treatment, according to the Scherrer equation, but still much smaller than that of $\mathrm{c}-\mathrm{Li}_{2} \mathrm{~S}(50 \mathrm{~nm})$. Note that the estimated crystalline sizes denoted here provide a lower bound and are primarily used as a relative comparison among the different $\mathrm{Li}_{2} \mathrm{~S}$ materials because use of the Scherrer equation assumes that the nanosize effect is the only (or predominant) factor in peak broadening. ${ }^{44}$ The crystal growth of $\mathrm{s}-\mathrm{Li}_{2} \mathrm{~S}$ during annealing is also corroborated by the SEM image in Figure 3C, which includes more secondary particles without clear boundaries among nanocrystals. In contrast, $\mathrm{c}-\mathrm{Li}_{2} \mathrm{~S}$ exists mainly as irregular microparticles of about $1-5 \mu \mathrm{m}$ diameter with some smaller particles of about $100 \mathrm{~nm}$, as shown in Figure 3D.

The electrochemical properties of both $s-\mathrm{Li}_{2} \mathrm{~S}$ and $\mathrm{c}-\mathrm{Li}_{2} \mathrm{~S}$ were examined in half-cells according to the slurry protocol described in the Experimental Section. Parts A and B of Figure 4 show the first four cycles of the CVs of $s-\mathrm{Li}_{2} \mathrm{~S}$ and $\mathrm{c}-\mathrm{Li}_{2} \mathrm{~S}$, respectively. The observed results are consistent with the typical behavior of $\mathrm{Li}-\mathrm{S}$ batteries reported in the literature. ${ }^{32,45}$ As is widely known, the material's speciation cycles between two extreme states of sulfur $\left(\mathrm{S}_{8}\right)$ at $1.5 \mathrm{~V}$ and $\mathrm{Li}_{2} \mathrm{~S}$ at $3.0 \mathrm{~V}$ through reactions $(5)-(9) .^{8,11}$

$$
\begin{aligned}
& 2 \mathrm{Li}^{+}+2 \mathrm{e}^{-}+\mathrm{S}_{8} \leftrightarrow \mathrm{Li}_{2} \mathrm{~S}_{8} \\
& 2 \mathrm{Li}^{+}+2 \mathrm{e}^{-}+3 \mathrm{Li}_{2} \mathrm{~S}_{8} \leftrightarrow 4 \mathrm{Li}_{2} \mathrm{~S}_{6} \\
& 2 \mathrm{Li}^{+}+2 \mathrm{e}^{-}+2 \mathrm{Li}_{2} \mathrm{~S}_{6} \leftrightarrow 3 \mathrm{Li}_{2} \mathrm{~S}_{4} \\
& 2 \mathrm{Li}^{+}+2 \mathrm{e}^{-}+\mathrm{Li}_{2} \mathrm{~S}_{4} \leftrightarrow 2 \mathrm{Li}_{2} \mathrm{~S}_{2} \\
& 2 \mathrm{Li}^{+}+2 \mathrm{e}^{-}+\mathrm{Li}_{2} \mathrm{~S}_{2} \leftrightarrow 2 \mathrm{Li}_{2} \mathrm{~S}
\end{aligned}
$$

In the case of $s-\mathrm{Li}_{2} \mathrm{~S}$, the initial open-circuit potential (OCP; $2.40 \mathrm{~V}$ vs $\left.\mathrm{Li} / \mathrm{Li}^{+}\right)$that lies between 3.0 and $1.5 \mathrm{~V}$ can be ascribed to self-delithiation of $\mathrm{Li}_{2} \mathrm{~S}$ to lithiate the carbon additive, whose OCP is about $2.9 \mathrm{~V} .{ }^{46}$ In the first half-cycle, the anodic current with a weak peak at $2.57 \mathrm{~V}$ (peak I) corresponds to delithiation of $\mathrm{Li}_{2} \mathrm{~S}$ to form sulfur. ${ }^{11,24}$ In the subsequent cathodic scans, three characteristic peaks are observed at ca. $2.44 \mathrm{~V}$ (peak II, strong), ca. $2.12 \mathrm{~V}$ (peak III, weak), and $1.94 \mathrm{~V}$ (peak IV, very strong), respectively. ${ }^{11,24}$ Peak II is typically assigned to the reduction of $S_{8}$ to polysulfides $\left(\mathrm{Li}_{2} \mathrm{~S}_{n}\right.$, where $n=$ 4-8) in three steps (eqs 5-7). Peak III is believed to result from the reduction of $\mathrm{Li}_{2} \mathrm{~S}_{4}$ to insoluble $\mathrm{Li}_{2} \mathrm{~S}_{2}$ (eq 8). ${ }^{11}$ Peak IV is due to the conversion of $\mathrm{Li}_{2} \mathrm{~S}_{2}$ to $\mathrm{Li}_{2} \mathrm{~S}$ (eq 9). ${ }^{11}$ In contrast, the subsequent anodic scans only have two distinguishable peaks at $2.39 \mathrm{~V}$ (peak V) and $2.53 \mathrm{~V}$ (peak VI), which correspond to the oxidation of $\mathrm{Li}_{2} \mathrm{~S}$ first to polysulfides and subsequently to $S_{8}$, respectively. The steady peak potentials and current intensities during the illustrated cycles in Figure 4A manifest the good stability and reversibility of the $s-\mathrm{Li}_{2} \mathrm{~S}$ electrode. The electrochemistry of the commercial c- $\mathrm{Li}_{2} \mathrm{~S}$ is quite similar because the six peaks just described are readily identified (Figure 4B). The prominent difference between the two materials is their stability. In the case of $\mathrm{c}-\mathrm{Li}_{2} \mathrm{~S}$, the anodic (cathodic) peaks shift more positive (negative) and the current intensities consecutively increase over the first few cycles, indicating the inferiority of $\mathrm{c}-\mathrm{Li}_{2} \mathrm{~S}$ to $\mathrm{s}-\mathrm{Li}_{2} \mathrm{~S}$ in electrolyte wettability and electrochemical reversibility. ${ }^{47}$

The galvanostatic technique was employed to assess the cycling stabilities (Figure 5) of $s-\mathrm{Li}_{2} \mathrm{~S}$ (red) and $\mathrm{c}-\mathrm{Li}_{2} \mathrm{~S}$ (blue) electrodes in both the charge (solid circles and squares) and discharge (open circles and squares) processes. $s-\mathrm{Li}_{2} \mathrm{~S}$ is superior to $\mathrm{c}-\mathrm{Li}_{2} \mathrm{~S}$ in all regards. The initial charge (delithiation) and discharge (lithiation) capacities for $\mathrm{s}-\mathrm{Li}_{2} \mathrm{~S}$ are 724 and 669 $\mathrm{mAh} / \mathrm{g}$, respectively, which compare well with the theoretical limit of $1166 \mathrm{mAh} / \mathrm{g}$ considering that electrode fabrication was not optimized. ${ }^{4}$ The performance gradually declines, and the half-life, defined as the cycles spent to reach $50 \%$ of the initial charge capacity, is 45 cycles for $s-\mathrm{Li}_{2} \mathrm{~S}$. Because $\mathrm{Li}_{2} \mathrm{~S}$ is in the 


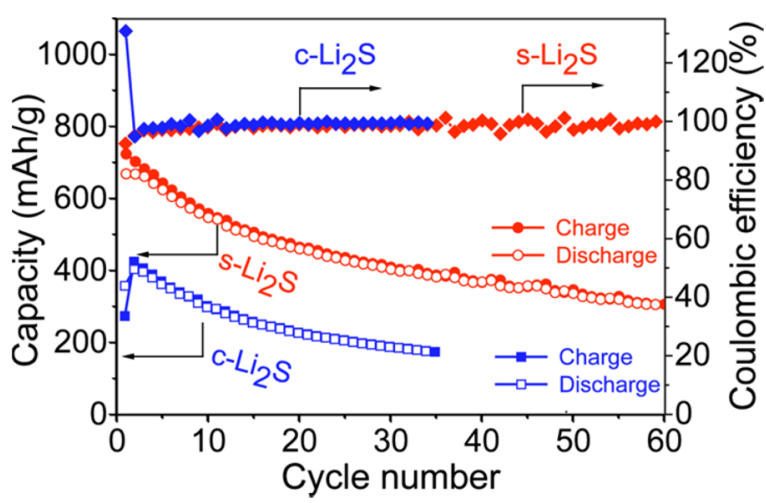

Figure 5. Typical plots of the specific capacity in charge (solid circles and squares) and discharge (open circles and squares) processes and $\mathrm{CE}$ (solid diamonds) versus cycle number for both s- $\mathrm{Li}_{2} \mathrm{~S}$ (red) and c$\mathrm{Li}_{2} \mathrm{~S}$ (blue), for which the galvanostatic current is $116.6 \mathrm{~mA} / \mathrm{g}(0.1 \mathrm{C}$, where $1 \mathrm{C}=1166 \mathrm{~mA} / \mathrm{g}$ ).

fully lithiated state, the Coulombic efficiency (CE) is defined as the ratio of lithiation (discharge) capacity to the delithiation (charge) capacity. ${ }^{48}$ The $\mathrm{s}-\mathrm{Li}_{2} \mathrm{~S}$ displayed $92 \% \mathrm{CE}$ in the first cycle and then quickly increased to $98-100 \%$ in all subsequent cycles.

In contrast, the initial charge capacity of the $c-\mathrm{Li}_{2} \mathrm{~S}$ is only $272 \mathrm{mAh} / \mathrm{g}$. The subsequent discharge capacity contributes 356 $\mathrm{mAh} / \mathrm{g}$, resulting in a "abnormally" high $\mathrm{CE}(\mathrm{CE}=356 / 272=$ $131 \%)$, which may be ascribed to the compensation for the loss of Li due to self-delithiation before the measurement and the dissolution of polysulfides during the discharge process, as pointed out in the literature. ${ }^{49-51}$ In the second cycle, the charge capacity bounces to $424 \mathrm{mAh} / \mathrm{g}$. The $\mathrm{CE}$ values in the subsequent cycles are comparable with those of $s-\mathrm{Li}_{2} \mathrm{~S}$. The stability $\mathrm{c}-\mathrm{Li}_{2} \mathrm{~S}$ declines in a similar fashion but reaches its halflife after only 23 cycles. The differences in the initial $\mathrm{CE}$ and stability suggest that $s-\mathrm{Li}_{2} \mathrm{~S}$ particles, compared with $c-\mathrm{Li}_{2} \mathrm{~S}$ particles, are better protected by the additives used in electrode fabrication because of their smaller particle sizes. Moreover, s$\mathrm{Li}_{2} \mathrm{~S}$ herein also performs significantly better than $\mathrm{c}-\mathrm{Li}_{2} \mathrm{~S}$ in the literature $(630 \mathrm{mAh} / \mathrm{g}$ for the initial capacity and $240 \mathrm{mAh} / \mathrm{g}$ at the 30 th cycle). ${ }^{9}$

Despite no optimization of the electrode fabrication procedure, the performance of $\mathrm{s}-\mathrm{Li}_{2} \mathrm{~S}$ synthesized in this work compares favorably with some $\mathrm{s}-\mathrm{Li}_{2} \mathrm{~S}$ particles in the literature. For instance, the $\mathrm{Li}_{2} \mathrm{~S}-\mathrm{C}$ nanocomposite made by reacting lithium sulfate with resorcinol/formaldehyde showed an initial capacity of $350 \mathrm{mAh} / \mathrm{g}$ and $300 \mathrm{mAh} / \mathrm{g}$ at the $30 \mathrm{th} \mathrm{cycle;}^{32}$ the $\mathrm{Li}_{2} \mathrm{~S}-\mathrm{C}$ nanocomposite made by thermally annealing a mixture of polysufilde $\mathrm{Li}_{2} \mathrm{~S}_{3}$ and polyacrylonitrile exhibited specific capacities of $500 \mathrm{mAh} / \mathrm{g}$ initially and $500 \mathrm{mAh} / \mathrm{g}$ at the 20th cycle; ${ }^{27}$ the $\mathrm{Li}_{2} \mathrm{~S}-\mathrm{C}$ nanocomposite made by ball-milling $\mathrm{Li}_{2} \mathrm{~S}$ micropowder and carbon precursor presented the specific capacity of $560 \mathrm{mAh} / \mathrm{g}$ initially and $420 \mathrm{mAh} / \mathrm{g}$ at the 30th cycle. $^{52} \mathrm{~s}-\mathrm{Li}_{2} \mathrm{~S}$ synthesized in this work displays a significantly higher initial (dis)charge capacity but inferior cycling stability. It is expected that the latter issue can be addressed through the optimization of electrode fabrication procedures, by following published strategies in the literature,,$^{4,9,12,26,53-56}$ a topic of our future work.

As shown in Figure 6, s- $\mathrm{Li}_{2} \mathrm{~S}$ and $\mathrm{c}-\mathrm{Li}_{2} \mathrm{~S}$ present different potential profiles in the first half-cycle (black). With respect to $\mathrm{s}-\mathrm{Li}_{2} \mathrm{~S}$, as highlighted by the inset of Figure $6 \mathrm{~A}$, a small potential barrier between 2.46 and $2.52 \mathrm{~V}$ is overcome to contribute the initial delithiation capacity of $50 \mathrm{mAh} / \mathrm{g}$. After that, only one plateau at $2.42 \mathrm{~V}$ is observed to contribute the remaining 670 $\mathrm{mAh} / \mathrm{g}$ before sharply rising to the cutoff potential $3.0 \mathrm{~V}$. In contrast, the potential profile of $\mathrm{c}-\mathrm{Li}_{2} \mathrm{~S}$ (Figure 6B, black) exhibits a flat plateau at $2.50 \mathrm{~V}$ for the initial $200 \mathrm{mAh} / \mathrm{g}$ and a sloping plateau between 2.8 and $3.0 \mathrm{~V}$ for the remaining 70 $\mathrm{mAh} / \mathrm{g}$. The first plateau can be considered to be a consequence of encountering a continuous potential barrier.

The potential profile of $s-\mathrm{Li}_{2} \mathrm{~S}$ described above confirms that this material does not require a significant potential to activate its charge capacity, consistent with literature reports for $\mathrm{Li}_{2} \mathrm{~S}$ nanoparticles. ${ }^{4,12,15,24,26,57}$ However, $\mathrm{Li}_{2} \mathrm{~S}$ micropowders reported in the literature require one to overcome a large activation barrier in the range of 3.5 and $4.0 \mathrm{~V} .{ }^{9}$ The activation process contributes only $48 \mathrm{mAh} / \mathrm{g}$, while the subsequent plateau at $2.5 \mathrm{~V}$ can contribute as high as $600 \mathrm{mAh} / \mathrm{g} .{ }^{9}$ Thus, our c- $\mathrm{Li}_{2} \mathrm{~S}$ electrode seems to behave partially like $\mathrm{Li}_{2} \mathrm{~S}$ nanoparticles and partially like $\mathrm{Li}_{2} \mathrm{~S}$ microparticles. When referring to our XRD result (which shows the crystalline sizes of $\mathrm{c}-\mathrm{Li}_{2} \mathrm{~S}$ to be $\geq 50 \mathrm{~nm}$ ) and SEM observation (some particles are around $100 \mathrm{~nm}$ ) in Figure 3, we speculate that the capacity observed in the $c-\mathrm{Li}_{2} \mathrm{~S}$ electrode be predominantly from those nano/submicroparticles; microparticles seem barely activated because of the requirement of higher cutoff potentials.

The potential profiles in the subsequent cycles corroborate the lithiation/deliathiation mechanism described in the discussion of the cyclic voltammetry results (Figure 4). Both $\mathrm{s}-\mathrm{Li}_{2} \mathrm{~S}$ and $\mathrm{c}-\mathrm{Li}_{2} \mathrm{~S}$ show three distinguishable plateaus during the discharge processes and two plateaus during the charge processes. For $s-\mathrm{Li}_{2} \mathrm{~S}$ (Figure 6A), the discharge plateaus are at $2.45 \mathrm{~V}$ (eqs 5-7), $2.2 \mathrm{~V}$ (eq 8), and $2.06 \mathrm{~V}$ (eq 9); the charge plateaus are at $2.25 \mathrm{~V}$ (eqs 8 and 9) and $2.50 \mathrm{~V}$ (eqs $5-7$ ). All of these values except 2.06 and $2.25 \mathrm{~V}$ are essentially
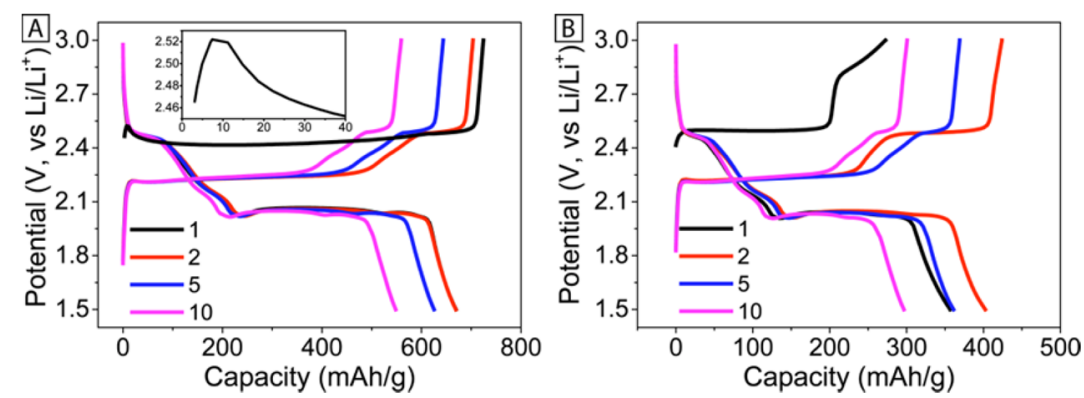

Figure 6. Several cycles of voltage profiles against the specific capacities for $\mathrm{s}-\mathrm{Li}_{2} \mathrm{~S}(\mathrm{~A})$ and $\mathrm{c}-\mathrm{Li}_{2} \mathrm{~S}(\mathrm{~B})$, where the inset in part A highlights the activation period in the first cycle. 
consistent with the corresponding peak potentials in the $\mathrm{CV}$ (Figure 4A). The small differences in the positions of these two peak potentials between the galvanostatic and cyclic voltammetric processes $(2.06 \mathrm{~V}$ vs $1.94 \mathrm{~V}$ and $2.25 \mathrm{~V}$ vs $2.39 \mathrm{~V})$ can be explained by the different reaction kinetics and polarization effects. In the case of $\mathrm{c}-\mathrm{Li}_{2} \mathrm{~S}$ (Figure $6 \mathrm{~B}$ ), while the charge plateau $(2.25 \mathrm{~V})$ is the same as that of $\mathrm{s}-\mathrm{Li}_{2} \mathrm{~S}$, the discharge plateau $(2.02 \mathrm{~V})$ is slightly lower, which means that, in principle, $\mathrm{s}-\mathrm{Li}_{2} \mathrm{~S}$ could provide higher energy and power densities than $\mathrm{c}-\mathrm{Li}_{2} \mathrm{~S}$. Moreover, it is worth noting that the potential hysteresis between the charge plateau $(2.25 \mathrm{~V})$ and the discharge plateau $(2.06 \mathrm{~V})$ for the $\mathrm{s}-\mathrm{Li}_{2} \mathrm{~S}$ electrode herein is only $0.19 \mathrm{~V}$ (lower than $0.23 \mathrm{~V}$ for $\mathrm{c}-\mathrm{Li}_{2} \mathrm{~S}$ ), comparable with the smallest value reported in the literature $(0.2 \mathrm{~V}),{ }^{12}$ where most values are in the range of $0.25-0.4 \mathrm{~V} .^{4,9,11}$ Small hysteresis is desirable and indicative of high voltage efficiency.

The electrochemical analyses above show that the s- $\mathrm{Li}_{2} \mathrm{~S}$ nanocrystals synthesized from reacting $\mathrm{H}_{2} \mathrm{~S}$ with Li-NAP hold promise as electrode materials for advanced rechargeable batteries. They are superior to commercial $c-\mathrm{Li}_{2} \mathrm{~S}$ in (dis)charge capacity, cycling stability, output voltage, and voltage efficiency. Despite simple electrode fabrication procedures, their performance is already comparable with some $s-\mathrm{Li}_{2} \mathrm{~S}$ materials reported in the literature.

\section{CONCLUSION}

In conclusion, we have demonstrated a new method of synthesizing anhydrous $\mathrm{Li}_{2} \mathrm{~S}$ nanocrystals and confirmed their promise as potential cathode materials for $\mathrm{Li}-\mathrm{S}$ batteries and advanced LIBs. The synthesis is realized by reacting Li-NAP with $\mathrm{H}_{2} \mathrm{~S}$, a thermodynamically spontaneous reaction at ambient temperature and pressure that is fast, complete, and irreversible. Compared with the commercial $\mathrm{Li}_{2} \mathrm{~S}$ micropowders (1- $5 \mu \mathrm{m})$, the synthesized $\mathrm{Li}_{2} \mathrm{~S}$ nanocrystals $(100 \mathrm{~nm}$ ) present a superior performance in all regards, including the (dis)charge capacity, cycling stability, output voltage, and voltage efficiency. These results clearly manifest the potential of this synthetic method for practical production of high-quality $\mathrm{Li}_{2} \mathrm{~S}$ nanoparticles because it is conducted at mild conditions and $\mathrm{Li}_{2} \mathrm{~S}$ is the only solid phase, facilitating separation and purification. Work is in progress to improve the battery performance through optimization of electrode fabrication and by tuning the morphology of $\mathrm{Li}_{2} \mathrm{~S}$ nanocrystals through the judicious choice of alternative complexing reagents and solvents.

\section{ASSOCIATED CONTENT}

\section{S Supporting Information}

The Supporting Information is available free of charge on the ACS Publications website at DOI: 10.1021/acsami.5b09367.

Schematic diagram and photograph of the apparatus as well as XRD patterns and SEM images of $\mathrm{Li}_{2} \mathrm{~S}$ produced by using different molar ratios of $\mathrm{Li}-\mathrm{NAP} / \mathrm{H}_{2} \mathrm{~S}$ (PDF)

\section{AUTHOR INFORMATION}

\section{Corresponding Authors}

*E-mail: cwolden@mines.edu.

*E-mail: yonyang@mines.edu.

\section{Author Contributions}

The manuscript was written through contributions of all authors. All authors have given approval to the final version of the manuscript.

\section{Funding}

This work is financially supported by the Startup Fund for Y.Y. from the Colorado School of Mines. C.A.W. acknowledges support by the National Science Foundation through Award DMR-1207294. C.B. acknowledges support by the Assistant Secretary for Energy Efficiency and Renewable Energy, Office of Vehicle Technologies of the U.S. Department of Energy under Contract No. DE-AC02-05CH11231, Subcontract No. DE-AC-36-08GO28308 under Exploratory Battery Materials Research program.

\section{Notes}

The authors declare no competing financial interest.

\section{ACKNOWLEDGMENTS}

We are thankful to Professor Yuan Yang for her helpful advice on NMR measurements.

\section{REFERENCES}

(1) Goodenough, J. B. Evolution of Strategies for Modern Rechargeable Batteries. Acc. Chem. Res. 2013, 46, 1053-1061.

(2) Whittingham, M. S. History, Evolution, and Future Status of Energy Storage. Proc. IEEE 2012, 100, 1518-1534.

(3) Tarascon, J. M.; Armand, M. Issues and Challenges Facing Rechargeable Lithium Batteries. Nature 2001, 414, 359-367.

(4) Wu, F.; Kim, H.; Magasinski, A.; Lee, J. T.; Lin, H.-T.; Yushin, G. Harnessing Steric Separation of Freshly Nucleated $\mathrm{Li}_{2} \mathrm{~S}$ Nanoparticles for Bottom-up Assembly of High-Performance Cathodes for LithiumSulfur and Lithium-Ion Batteries. Adv. Energy Mater. 2014, 4, 1400196.

(5) Bruce, P. G.; Freunberger, S. A.; Hardwick, L. J.; Tarascon, J. M. Li-O(2) and Li-S Batteries with High Energy Storage. Nat. Mater. 2012, 11, 19-29.

(6) Manthiram, A.; Fu, Y.; Su, Y.-S. Challenges and Prospects of Lithium-Sulfur Batteries. Acc. Chem. Res. 2013, 46, 1125-1134.

(7) Evers, S.; Nazar, L. F. New Approaches for High Energy Density Lithium-Sulfur Battery Cathodes. Acc. Chem. Res. 2013, 46, 11351143.

(8) Yin, Y. X.; Xin, S.; Guo, Y. G.; Wan, L. J. Lithium-Sulfur Batteries: Electrochemistry, Materials, and Prospects. Angew. Chem., Int. Ed. 2013, 52, 13186-13200.

(9) Yang, Y.; Zheng, G.; Misra, S.; Nelson, J.; Toney, M. F.; Cui, Y. High-Capacity Micrometer-Sized $\mathrm{Li}_{2} \mathrm{~S}$ Particles as Cathode Materials for Advanced Rechargeable Lithium-Ion Batteries. J. Am. Chem. Soc. 2012, 134, 15387-15394.

(10) Mikhaylik, Y.; Kovalev, I.; Schock, R.; Kumaresan, K.; Xu, J.; Affinito, J. High Energy Rechargeable Li-S Cells for EV Application. Status, Remaining Problems and Solutions. ECS Trans. 2010, 25, 2334.

(11) Yang, Y.; Zheng, G. Y.; Cui, Y. Nanostructured Sulfur Cathodes. Chem. Soc. Rev. 2013, 42, 3018-3032.

(12) Yang, Y.; McDowell, M. T.; Jackson, A.; Cha, J. J.; Hong, S. S.; Cui, Y. New Nanostructured $\mathrm{Li}_{2} \mathrm{~S} /$ Silicon Rechargeable Battery with High Specific Energy. Nano Lett. 2010, 10, 1486-1491.

(13) Seh, Z. W.; Li, W. Y.; Cha, J. J.; Zheng, G. Y.; Yang, Y.; McDowell, M. T.; Hsu, P. C.; Cui, Y. Sulphur-TiO 2 Yolk-Shell Nanoarchitecture with Internal Void Space for Long-Cycle LithiumSulphur Batteries. Nat. Commun. 2013, 4, 1331.

(14) Zhou, W.; Yu, Y.; Chen, H.; DiSalvo, F. J.; Abruna, H. D. Yolk@ Shell Structure of Polyaniline-Coated Sulfur for Lithium-Sulfur Batteries. J. Am. Chem. Soc. 2013, 135, 16736-16743.

(15) Zhang, K.; Wang, L.; Hu, Z.; Cheng, F.; Chen, J. Ultrasmall $\mathrm{Li}_{2} \mathrm{~S}$ Nanoparticles Anchored in Graphene Nanosheets for High-Energy Lithium-Ion Batteries. Sci. Rep. 2014, 4, 6467.

(16) Ikeda, N.; Yamamoto, K. Method of Manufacturing Lithium Sulfide. Patent EP0802159 B1, 2001.

(17) Miyashita, N. Method for Producing Lithium Sulfide for Lithium Ion Cell Solid Electrolyte Material. U.S. Patent 20140037535 A1, 2014. 
(18) Hofmann, A. F.; Fronczek, D. N.; Bessler, W. G. Mechanistic Modeling of Polysulfide Shuttle and Capacity Loss in Lithium-Sulfur Batteries. J. Power Sources 2014, 259, 300-310.

(19) Lide, D. R. CRC Handbook of Chemistry and Physics, 88th ed.; CRC Press, Taylor \& Francis Group: New York, 2007-2008.

(20) Takeuchi, T.; Sakaebe, H.; Kageyama, H.; Senoh, H.; Sakai, T.; Tatsumi, K. Preparation of Electrochemically Active Lithium SulfideCarbon Composites using Spark-Plasma-Sintering Process. J. Power Sources 2010, 195, 2928-2934.

(21) Agostini, M.; Hassoun, J.; Liu, J.; Jeong, M.; Nara, H.; Momma, T.; Osaka, T.; Sun, Y. K.; Scrosati, B. A Lithium-Ion Sulfur Battery Based on a Carbon-Coated Lithium-Sulfide Cathode and an Electrodeposited Silicon-Based Anode. ACS Appl. Mater. Interfaces 2014, 6, 10924-10928.

(22) Hassoun, J.; Scrosati, B. A High-Performance Polymer Tin Sulfur Lithium Ion Battery. Angew. Chem., Int. Ed. 2010, 49, 23712374.

(23) Nagao, M.; Hayashi, A.; Tatsumisago, M. High-Capacity $\mathrm{Li}_{2} \mathrm{~S}$ Nanocarbon Composite Electrode for All-Solid-State Rechargeable Lithium Batteries. J. Mater. Chem. 2012, 22, 10015-10020.

(24) Cai, K.; Song, M.-K. K.; Cairns, E. J.; Zhang, Y. Nanostructured $\mathrm{Li}_{2} \mathrm{~S}-\mathrm{C}$ Composites as Cathode Material for High-energy Lithium/ Sulfur Batteries. Nano Lett. 2012, 12, 6474-6479.

(25) Wu, F.; Magasinski, A.; Yushin, G. Nanoporous $\mathrm{Li}_{2} \mathrm{~S}$ and MWCNT-linked $\mathrm{Li}_{2} \mathrm{~S}$ powder cathodes for lithium-sulfur and lithiumion battery chemistries. J. Mater. Chem. A 2014, 2, 6064-6070.

(26) Wang, C.; Wang, X.; Yang, Y.; Kushima, A.; Chen, J.; Huang, Y.; $\mathrm{Li}$, J. Slurryless $\mathrm{Li}_{2} \mathrm{~S} /$ Reduced Graphene Oxide Cathode Paper for High-Performance Lithium Sulfur Battery. Nano Lett. 2015, 15, 17961802.

(27) Guo, J.; Yang, Z.; Yu, Y.; Abruña, H. D.; Archer, L. A. LithiumSulfur Battery Cathode Enabled by Lithium-Nitrile Interaction. J. Am. Chem. Soc. 2013, 135, 763-767.

(28) Han, K.; Shen, J. M.; Hayner, C. M.; Ye, H. Q.; Kung, M. C.; Kung, H. H. Li $\mathrm{L}_{2} \mathrm{~S}$-Reduced Graphene Oxide Nanocomposites as Cathode Material for Lithium Sulfur Batteries. J. Power Sources 2014, 251, 331-337.

(29) Hwa, Y.; Zhao, J.; Cairns, E. J. Lithium Sulfide $\left(\mathrm{Li}_{2} \mathrm{~S}\right) / \mathrm{Graphene}$ Oxide Nanospheres with Conformal Carbon Coating as a High-Rate, Long-Life Cathode for Li/S Cells. Nano Lett. 2015, 15, 3479-3486.

(30) Lin, Z.; Liu, Z. C.; Dudney, N. J.; Liang, C. D. Lithium Superionic Sulfide Cathode for All-Solid Lithium-Sulfur Batteries. ACS Nano 2013, 7, 2829-2833.

(31) Zheng, S. Y.; Chen, Y.; Xu, Y. H.; Yi, F.; Zhu, Y. J.; Liu, Y. H.; Yang, J. H.; Wang, C. S. In Situ Formed Lithium Sulfide/Microporous Carbon Cathodes for Lithium-Ion Batteries. ACS Nano 2013, 7, 10995-11003.

(32) Yang, Z.; Guo, J.; Das, S. K.; Yu, Y.; Zhou, Z.; Abruna, H. D.; Archer, L. A. In situ Synthesis of Lithium Sulfide-Carbon Composites as Cathode Materials for Rechargeable Lithium Batteries. J. Mater. Chem. A 2013, 1, 1433-1440.

(33) Kohl, M.; Bruckner, J.; Bauer, I.; Althues, H.; Kaskel, S. Synthesis of Highly Electrochemically Active $\mathrm{Li}_{2} \mathrm{~S}$ Nanoparticles for Lithium-Sulfur-Batteries. J. Mater. Chem. A 2015, 3, 16307-16312.

(34) Meng, X. B.; Comstock, D. J.; Fister, T. T.; Elam, J. W. VaporPhase Atomic-Controllable Growth of Amorphous $\mathrm{Li}_{2} \mathrm{~S}$ for HighPerformance Lithium-Sulfur Batteries. ACS Nano 2014, 8, 1096310972.

(35) Li, X. M.; Morrish, R. M.; Yang, Y.; Wolden, C. A.; Yang, Y. Thermodynamically Favorable Conversion of Hydrogen Sulfide to Valuable Products through Reaction with Sodium Naphthalenide. ChemPlusChem 2015, 80, 1508-1512.

(36) Cloud, J. E.; Wang, Y.; Li, X.; Yoder, T. S.; Yang, Y.; Yang, Y. Lithium Silicide Nanocrystals: Synthesis, Chemical Stability, Thermal Stability, and Carbon Encapsulation. Inorg. Chem. 2014, 53, 1128911297.

(37) Cheng, Y.; Fan, H. F.; Wu, S. X.; Wang, Q. A.; Guo, J.; Gao, L.; Zong, B. N.; Han, B. X. Enhancing the Selectivity of the
Hydrogenation of Naphthalene to Tetralin by High Temperature Water. Green Chem. 2009, 11, 1061-1065.

(38) Japan National Institute of Advanced Industrial Science and Technology (AIST). Spectral Database for Organic Compounds, S.D.B.S.

(39) Tsimeli, K.; Triantis, T. M.; Dimotikali, D.; Hiskia, A. Development of a Rapid and Sensitive Method for the Simultaneous Determination of 1,2-Dibromoethane, 1,4-Dichlorobenzene and Naphthalene Residues in Honey Using HS-SPME Coupled with GC-MS. Anal. Chim. Acta 2008, 617, 64-71.

(40) NIST-MS-Search, NIST14, and Wiley databases, 2014.

(41) Jones, J. H.; Thomas, J. S. CCCLXXXIX.-The Action of Hydrogen Sulphide on Lithium Ethoxide. Lithium Hydrosulphide. J. Chem. Soc., Trans. 1923, 123, 3285-3294.

(42) Verma, N. K.; Khanna, S. K.; Kapila, B. Comprehensive Chemistry XI; Laxmi Publications: New Delhi, India, 2010; Chapter 10.

(43) Zhao, J.; Lu, Z.; Wang, H.; Liu, W.; Lee, H.-W.; Yan, K.; Zhuo, D.; Lin, D.; Liu, N.; Cui, Y. Artificial Solid Electrolyte InterphaseProtected $\mathrm{Li}_{\mathrm{x}} \mathrm{Si}$ Nanoparticles: An Efficient and Stable Prelithiation Reagent for Lithium-Ion Batteries. J. Am. Chem. Soc. 2015, 137, 83728375.

(44) Patterson, A. The Scherrer Formula for X-Ray Particle Size Determination. Phys. Rev. 1939, 56, 978-982.

(45) Fu, Y.; Su, Y.-S.; Manthiram, A. Li ${ }_{2}$ S-Carbon Sandwiched Electrodes with Superior Performance for Lithium-Sulfur Batteries. Adv. Energy Mater. 2014, 4, 1300655.

(46) Zhao, M. C.; Xu, M. M.; Dewald, H. D.; Staniewicz, R. J. OpenCircuit Voltage Study of Graphite-Coated Copper Foil Electrodes in Lithium-Ion Battery Electrolytes. J. Electrochem. Soc. 2003, 150, A117A120.

(47) Zheng, J.; Lv, D.; Gu, M.; Wang, C.; Zhang, J.-G.; Liu, J.; Xiao, J. How to Obtain Reproducible Results for Lithium Sulfur Batteries? J. Electrochem. Soc. 2013, 160, A2288-A2292.

(48) Jayaprakash, N.; Shen, J.; Moganty, S. S.; Corona, A.; Archer, L. A. Porous Hollow Carbon@Sulfur Composites for High-Power Lithium-Sulfur Batteries. Angew. Chem., Int. Ed. 2011, 50, 5904-5908.

(49) Xin, S.; Gu, L.; Zhao, N. H.; Yin, Y. X.; Zhou, L. J.; Guo, Y. G.; Wan, L. J. Smaller Sulfur Molecules Promise Better Lithium-Sulfur Batteries. J. Am. Chem. Soc. 2012, 134, 18510-18513.

(50) Zhang, B.; Qin, X.; Li, G. R.; Gao, X. P. Enhancement of long stability of sulfur cathode by encapsulating sulfur into micropores of carbon spheres. Energy Environ. Sci. 2010, 3, 1531-1537.

(51) Xi, K.; Kidambi, P. R.; Chen, R.; Gao, C.; Peng, X.; Ducati, C.; Hofmann, S.; Kumar, R. V. Binder free three-dimensional sulphur/fewlayer graphene foam cathode with enhanced high-rate capability for rechargeable lithium sulphur batteries. Nanoscale 2014, 6, 5746-5753.

(52) Jeong, S.; Bresser, D.; Buchholz, D.; Winter, M.; Passerini, S. Carbon Coated Lithium Sulfide Particles for Lithium Battery Cathodes. J. Power Sources 2013, 235, 220-225.

(53) Shin, J. H.; Cairns, E. J. N-Methyl-(n-butyl)pyrrolidinium bis(trifluoromethanesulfonyl)imide-LiTFSI-poly(ethylene glycol) dimethyl ether mixture as a $\mathrm{Li} / \mathrm{S}$ cell electrolyte. J. Power Sources 2008, $177,537-545$.

(54) Su, Y. S.; Manthiram, A. Lithium-Sulphur Batteries with a Microporous Carbon Paper as a Bifunctional Interlayer. Nat. Commun. 2012, 3, 1166.

(55) Chung, S.-H.; Manthiram, A. A Hierarchical Carbonized Paper with Controllable Thickness as a Modulable Interlayer System for High Performance Li-S Batteries. Chem. Commun. 2014, 50, 41844187.

(56) Balach, J.; Jaumann, T.; Klose, M.; Oswald, S.; Eckert, J.; Giebeler, L. Mesoporous Carbon Interlayers with Tailored Pore Volume as Polysulfide Reservoir for High-Energy Lithium-Sulfur Batteries. J. Phys. Chem. C 2015, 119, 4580-4587.

(57) Ye, F. M.; Hou, Y.; Liu, M. N.; Li, W. F.; Yang, X. W.; Qiu, Y. C.; Zhou, L. S.; Li, H. F.; Xu, Y. J.; Zhang, Y. G. Fabrication of Mesoporous $\mathrm{Li}_{2} \mathrm{~S}-\mathrm{C}$ Nanofibers for High Performance $\mathrm{Li} / \mathrm{Li}_{2} \mathrm{~S}$ Cell Cathodes. Nanoscale 2015, 7, 9472-9476. 